


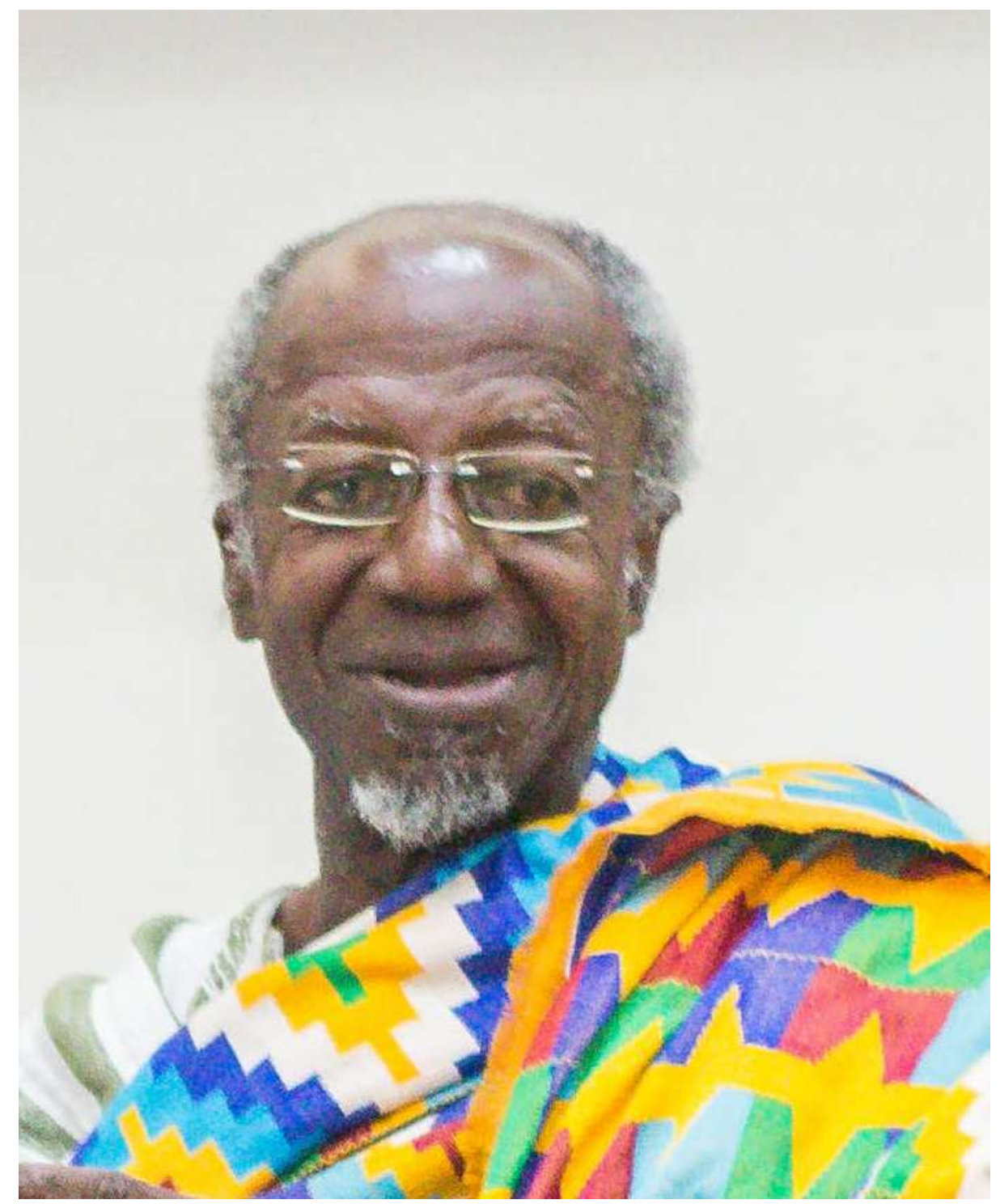

PROFESSOR ATTA GYAMFI BRITWUM 


\section{THE BILINGUAL LITERARY JOURNAL OF THE FACULTY OF ARTS UNIVERSITY OF CAPE COAST}

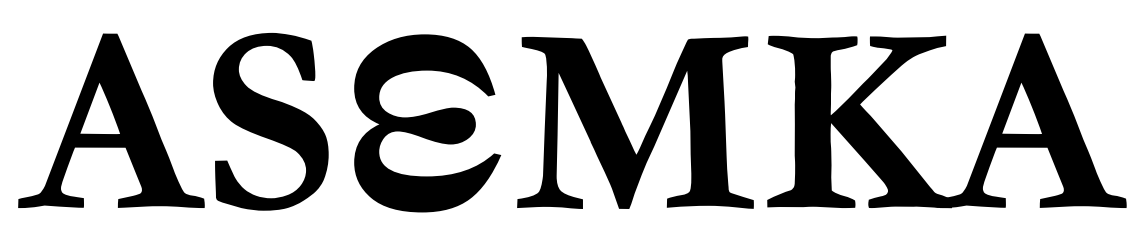

NUMBER 10

SEPTEMBER 2020

\section{EDITORIAL COMMITTEE}

Editor-in-Chief: Prof. Samuel Awuah-Nyamekye (Ph.D.)

Editor: $\quad$ Prof. Mawuloe Koffi Kodah (Ph.D.)

Associate Editors: Dr. Samuel Kwesi Nkansah

Dr. Mrs. Theresa Addai Munumkum

Dr. Isaac Mwinlaaru

Business Editor: Rev. Sr. Dr. Matilda Alice Nsiah

\section{EDITORIAL STAFF}

Mr. Stephen Owusu-Amoh

Mr. Isaac Kweku Grantson

\section{EDITORIAL ADVISORS}

Prof. Kwadwo Opoku-Agyemang, University of Cape Coast.

Prof. Joseph B. A. Afful, University of Cape Coast.

Prof. Raymond N. Osei, University of Cape Coast.

Prof. Richard V. Cudjoe, University of Cape Coast.

Prof. Victor K Yankah, University of Cape Coast.

Dr. Mousa Traore, University of Cape Coast. 


\section{ACKNOWLEDGEMENTS}

We acknowledge the contribution of the underlisted members of the Department of French who did preliminary editorial work on the papers:

Dr. Anthony Y.M. De-Souza (Chairman)

Prof. Raymond N. Osei

Prof. Mawuloe K. Kodah

Dr. Sylvester P. Krakue

Mr. Ofosu Addo-Danquah

Mr. Micheal Donkoh (Secretary)

\section{SUBSCRIPTION}

Assmka is published twice in the Academic year by the Faculty of Arts, University of Cape Coast. The annual out-of-Ghana subscription rate, including air-postage, is US\$29 for individuals, and US\$ 59 for institutions and libraries. Single issue rate for individuals is US\$18. Claims for copies not received must be made within three (3) months following an issue's publication. Correspondence should be addressed to:

The Editor, Assmka

Department of French

Faculty of Arts

College of Humanities and Legal Studies

University of Cape Coast

Cape Coast

Ghana, West Africa

Email: asemkajournal@ucc.edu.gh

\section{ADVERTISING}

Advertising rate, size specifications and related information are available upon request. Please, contact the General Editor for more information.

\section{SUBMISSIONS}

Assmka is an internationally-refereed journal of the Humanities. It publishes scholarly and imaginative articles in Literature, Language, and Culture generally, including, Orature, Film, Theatre, Music and Art. Essays, Interviews, Book Reviews, Poetry, Short Prose Fiction and Drama are welcome. Submitted manuscripts, in English and French, must be prepared in accordance with the most recent of APA or MLA style manual, where applicable. The author's identity and address may appear only on the cover- 
page and nowhere else within the submitted manuscript. All manuscripts should be submitted electronically through:

asemkajournal@ucc.edu.gh

Manuscript will be duly acknowledged within two (2) months of receiving them. Individuals whose works are accepted for publication may provide Assmka with a brief bio-data. The Editors cannot be held liable for lost or damaged manuscripts. Material published by Assmka does not necessarily represent the views of the Journal's Editors, Staff, Financial Supporters or the University of Cape Coast and its affiliates. These parties disavow any legal responsibility related to all submitted material.

\section{BACK ISSUES}

Back issues of Ascmka that are in stock may be ordered from the Editor at US\$20 per copy.

\section{GRANT SUPPORT}

Assmka is funded through grants from the Office of the Dean, Faculty of Arts; the Publications' Board; and the Office of the Vice-Chancellor, University of Cape Coast, Cape Coast, Ghana.

No part of this Journal may be reproduced, stored in a retrieval system, or transmitted in any manner whatsoever without express permission from the Editors, except in the case of brief quotations embodied in critical Articles and Reviews.

Copyright (C2020 by The Editors and The Faculty of Arts, University of Cape Coast. The cover and page design elements were inspired by the Adinkra symbols of Ghana. 


\section{DEDICATION \\ PROFESSOR ATTA GYAMFI BRITWUM}

Professor Britwum is a man of many parts. He is as much at home with Marxist Economic Theory and Feminist Sociological Thoughts, as he is with French and Francophone Literatures. He is a great teacher and Administrator of international acclaim. The Editors dedicate this special issue of Assmka to his honour. 


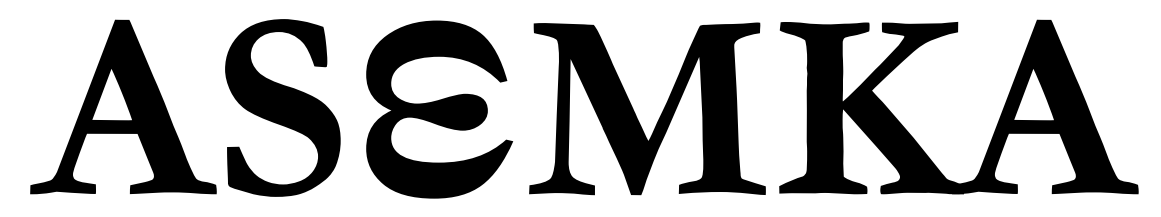

NUMBER 10

SEPTEMBER 2020 


\section{CONTENTS}

$\begin{array}{llll}\text { Editorial Committee } & \sim & \sim & \sim i i \\ \text { Editorial Staff } & \sim & \sim & \sim i i \\ \text { Editorial Advisors } & \sim & \sim & \sim i i \\ \text { Acknowledgements } & \sim & \sim & \sim i i i \\ \text { Subscription } & \sim & \sim & \sim i i i \\ \text { Advertising } & \sim & \sim & \sim i i i \\ \text { Submissions } & \sim & \sim & \sim i i i \\ \text { Back Issues } & \sim & \sim & \sim i v \\ \text { Grant Support } & \sim & \sim & \sim i v \\ \text { Dedication } \sim & \sim & \sim & \sim \\ \text { Foreword } \sim & \sim & \sim & \sim x \\ \text { Assmka: Editorial } & \sim & \sim & x i-x v i i\end{array}$

Articles

First Section - French

Britwum, A. G.

Insuffisances Théoriques Des Damnés De La Terre De

Frantz Fanon

$\sim$

$\sim 2-15$

Kodah, M. K.

Disculpation de Dieu dans le malheur des hommes:

Une lecture critique de Gouverneurs de la rosée de

Jacques Roumain $\sim \sim \sim 16-31$

Addo-Danquah, $O$.

Le récit de pensées: Une analyse comparative de Vol de nuit d'Antoine de Saint-Exupéry et La Condition humaine d'André Malraux

Kodah, M. K. \& Togoh, A. A. X.

Réactions des femmes face au conflit de genre dans C'est le soleil qui m'a brûlée et Tu t'appelleras Tanga de Calixthe Beyala

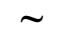

$\sim$

$\sim \quad 45-59$ 
Kudi, M. D.

La Littérature francophone face aux médias de télécommunication : Une nouvelle dynamique de la création romanesque, le cas de L'Énigme de retour et Tout bouge autour de moi de Dany Laferrière $\sim \quad$ 60-72

Gli, $M$.

Les faces du bonheur dans Vol de nuit d'Antoine de Saint-Exupéry $\sim \sim 73-85$

Krakue, S. P.

Christ haïtien : Gouverneurs de la rosée et La Bible $\sim 86-93$

Afari, E. S. K. \& Yegblemenawo, C. A. A.

Apports de la télésérie à l'amélioration de la compétence d'expression orale du FLE à l'école normale $\sim 94-116$

Bationo, J.-Cl.

Didactique de la littérature et littérature didactique:

l'exemple de la littérature africaine francophone en classe de langues étrangères au Burkina Faso

Second Section - English

Krakue, S. P.

Quod erat demonstrandum: A comparative study of narrative technique in Ama Ata Aidoo's Changes and Albert Camus'

Les justes (The Just Ones) 〜 $\sim$ $133-141$

Adjandeh, E. A.

Analysis of Wole Soyinka's Trials of Brother Jero in Relation to Ghanaian Religious Discourse

Sam, C. A.

Decolonizing the Postcolony: Of Men, Spatial Politics and the New Nation in WA Thiongo's Wizard of the Crow.

Kambou, M. K. \& Traore, S. A.

Manipulation and the popular uprising in Burkina Faso in 2014. $\sim \quad \sim 172-189$ 
De-Soura, A. Y.M.

Test-taking Strategies of University of Cape Coast Students of

French as a Foreign Language: a Case Study $\sim 191-216$

Kambou, M. K. \& Soma, L.

Local Culture and EFL Vocabulary Learning $\sim \quad 217-238$

Kabore, A. \& Nazortin, C.

Critical Analysis of the Place and Importance of Literature in the Teaching / Learning of English and in School Leaving Certificate Examination in Burkina Faso from 1985 to 2018

Malgoubri, I., Sawadogo, M. \& Kambou, M. K.

Digital Audio-visuals Aids and Listening in English as a

Foreign Language Classrooms

Osei, R. N. \& Inusah, $H$.

A Critique of the Images of Heaven in the Scriptures of the

Abrahamic Religions: An Existentialist Perspective $\sim$ 270- 282

Negedu, A. K.

Lexical Gaps and Ideological Shift in the Translation of

Chinua Achebe's Things Fall Apart as "Le Monde

S'effondre" in French $\sim \sim 283-297$

Talburt, $T$.

Political Transformation and Development in Africa:

Lessons from Achebe's Things Fall Apart

$\sim 298-313$ 


\section{FORWORD}

All the papers in this Volume were presented at a three-day Conference in honour of Professor Atta Gyamfi Britwum who turns eighty years in March 2021. Most of those years he spent at University of Cape Coast, having cut his teeth as a young lecturer in French language and Literature-in-French in 1974. After many years of an illustrious career in teaching, publication and extension, he bowed out at age seventy, but he didn't get the well-deserved rest he was entitled to; he continues to support his Department and the University as a whole. Today, Professor Britwum's name is associated with high standards of professionalism which earned him the nickname 'L'oracle'. Indeed, it is impossible to find another name universally acknowledged as embodying the excellence in French education offered at the Department of French, University of Cape Coast.

The decision to honour Professor Britwum couldn't have been taken at a more appropriate time. It was planned to coincide with the fiftieth anniversary of the publication of the Beautyful ones are not yet Born, Ayi Kwei Armah's first novel. Britwum never grew tired of reading, teaching and examining it. Such was his respect for Armah's craft. So, the three-day Conference was as much a celebration of Armah's contribution to the shaping of the African novel as it was a tribute to Professor Britwum's work as a teacher of literature of immense influence.

One only has to look at the titles of the papers published in this Volume to get an idea of how deep his influence runs at UCC and beyond. Most of the contributors once upon a time sat at the master's feet, but are now scholars in their own right keeping the flame of French scholarship burning bright (George Cooper: "Polished in a high degree, as each froggie ought to be/Now they sit on other logs, teaching other little frogs.") A good number of the papers are on Literature, nonetheless not limited to Armah's works. No Surprise there. Nevertheless, there are Language papers there too. No surprise here either, for the man to whose honour the Volume is dedicated is equally at home in both Language and Literature

\section{Lawrence $K$. Owusu-Ansah,}

Department of English, UCC.

A Disciple 


\section{$A S E M K A:$ EDITORIAL}

This Special Edition of $A S E M K A$, a bilingual literary journal of the University of Cape Coast, is published in honour of Prof. Atta Gyamfi Britwum, a revered Associate Professor of Francophone African Literature and Civilisation in the Department of French, U.C.C. It contains twenty (20) papers centred on diverse areas of teaching and research in the Humanities and on the theme of the Conference - Literature and the Humanities in the 21 Century: Interdisciplinary Perspectives - held in his honour by the Department of French, University of Cape Coast, Ghana, $13^{\text {th }}-15^{\text {th }}$ Mars, 2019. To reflect Prof. Britwum's area of research interest, the essays are arranged in two sections according to his dominant medium of instruction (French language) and speciality (Literature and Civilisation), followed by those in English language. The first section consists of a set of nine (9) essays in French spanning between themes in Literature and Language. The second section is made up of a set of eleven (11) essays in English which examine issues in literary studies, Language and Didactics, ICT and French Education, Philosophy, and Translation, among others. This special arrangement is however representative of the bilingual nature of the Journal.

\section{First Section}

Britwum, A. G.'s paper titled, “Insuffisances Théoriques Des Damnés De La Terre De Frantz Fanon", presents the Fanonian perspective as a complement to the African nationalism that informed anticolonial struggles. The study posits that African nationalism, populist in nature, for failing to target the capitalist economic base, which defines colonialism, ended up strengthening it. It concludes that Fanon's anticolonialist perspective, despite its overt radicalism, is not designed to allow a "bottom-to-top change" in colonial / capitalist society.

Kodah, M. K.'s paper titled, "Disculpation de Dieu dans le malheur des hommes: Une lecture critique de Gouverneurs de la rosée de Jacques Roumain", puts into question the responsibility of God in the suffering of men on earth and the capacity of man to make and unmake himself. The study aims at absolving God of the guilt of the miseries of men, and also questioning the atheistic or anti-religion denunciation of this narrative 
text since its publication. The study is accomplished through a critical reading and a thoughtful analysis of Jacques Roumain's Gouverneurs de la rosée within the analytical structure of literary studies and sociocriticism.

Addo-Danquah, O.'s paper, "Le récit de pensées : Une analyse comparative de Vol de nuit d'Antoine de Saint-Exupéry et La Condition humaine d'André Malraux", drawing inspirations from theorists such as Léon Edel (1961) and later Dorrit Cohn (1981), examines what Antoine de Saint-Exupéry's Vol de nuit by and André Malraux's La Condition bumaine respectively can offer on the side of representations of the interior life. The study is posited within the framework of narratological theories.

Kodah, M. K. \& Togoh Tchimavor, A. A. in "Réactions des femmes face au conflit de genre dans C'est le soleil qui m'a brûlée et Tu t'appelleras Tanga de Calixthe Beyala" examine the reactions of women to gender conflict in Calixthe Beyala's C'est le soleil qui m'a brulée and Tu t'appelleras Tanga. The study critically reflects on the various ways women in Beyala's C'est le soleil qui m'a brulée and Tu t'appelleras Tanga react to oppression and exploitation resulting from patriarchal domination. It therefore examines the sources and nature of this conflict, and how women react to it in the two novels. The study points to the fact that, much as conflict emanating from patriarchal oppression and male's domination in human societies is inimical to the rights of women, the methods used by the latter to free themselves from this state of being remain questionable, in that, these methods defy rational thinking and are also a kind of reversal oppression and domination which are equally unacceptable.

Kudi, M. D.’s paper, “La Littérature francophone face aux médias de télécommunication: Une nouvelle dynamique de la création romanesque, le cas de L'Énigme de retour et Tout bouge autour de moi de Dany Laferrière", seeks to examine how pertinent painting, photography, television, telephone etc. are to the production of the contemporary Francophone novel. The study focuses on L'Énigme de retour (2009) and Tout bouge autour de moi (2011). The analysis is based on the perspective of literary intermediality propounded by Jürgen E. Muller which is characterised by an interaction between telecommunication media and literary text. The study establishes through these selected novels that these media forms are not simply another form of expression in the novel but rather a lens through which the story is narrated. 
Gli, M.'s paper titled, "Les faces du bonheur dans Vol de nuit d'Antoine de Saint-Exupéry", analyses the faces of happiness in Antoine de Saint-Exupéry's Vol de Nuit. The study is conducted through thematic approach. This approach is complemented by Maslow's theory of human needs. The collection of data or the collection of information is purely documentary. The study therefore seeks to establish a link between individual happiness and collective happiness in Saint-Exupéry's selected narrative text.

Krakue, S. P.'s paper, “Christ haïtien : Gouverneurs de la rosée et La Bible", attempts to question Jacques Roumain's Gouverneurs de la rosée in order to elucidate the novelist's use of the biblical text in his creative activity. The study demonstrates that Jacques Roumain's narrative text turns out to borrow biblical ideas not only to develop his plot but also to design his main character.

Afari, E. S. K. \& Yegblemenawo, C. A. A. in “Apports de la télésérie à l'amélioration de la compétence d'expression orale du FLE à l'école normale." examine the impact examine the impact of the use of serial movies as teaching aid on oral expression of French language learners in Colleges of Education in Ghana with the aid of smartphones. The study discovers that the use of serial movies in teaching French boosts learners' performance in oral communication. It therefore recommends that serial movies could be used in teaching French language lessons in order to enhance the oral communication competencies among learners.

Bationo, J.-Cl.'s paper titled, "Didactique de la littérature et littérature didactique : l'exemple de la littérature africaine francophone en classe de langues étrangères au Burkina Faso", shows not only how to teach literature in language class but also how to use didactic literature to develop social skills among learners to reduce vandalism, school violence, negative stereotypes, misunderstandings of intercultural nature while cultivating social peace and living together in a context of internationalization, globalization and digital revolution. The paper focuses on francophone African Literature and posits that methodological approach used for the didactic transpositions of literary content is based on the new orientation and the redefinition of the objectives of language teaching and on the didactic models of the aesthetic reception of didactics of literature which requires putting the learner in intensive interaction with the text and motivating him/her to express himself/herself on his/her reading experiences. 


\section{SECOND SECTION - ENGLISH}

Krakue, S. P.'s paper titled, “Quod erat demonstrandum: A comparative study of narrative technique in Ama Ata Aidoo's Changes and Albert Camus' Les justes (The Just Ones)", demonstrates through textual analysis, how in Ama Ata Aidoo's Changes and Albert Camus Les justes, the authors resort to a specific form of irony to bring the discussion of issues raised to a conclusion. The technique consists in demonstrating clearly a huge discrepancy between a "fine" idea and its practical usefulness. Both authors successfully use narrative technique. Albert Camus demonstrates the hollowness of the idea of fighting for justice through revolutionary violence and Ama Ata Aidoo similarly demonstrates the fatuousness of the theory of women-emancipation-through-polygamy.

Adjandeh, E. A. analyses selected reports in Ghanaian media in relation to the clergy and identifies how Wole Soyinka's theme is reflected in these media in her paper titled, "Analysis of Wole Soyinka's Trials of Brother Jero in Relation to Ghanaian Religious Discourse". The study seeks to examine the extent to which themes in Soyinka's Trials of brother Jero play out in religious discourses in Ghana. The global nature of the issues problematized by Wole Soyinka also comes out through this study as the work set in Nigeria is analyzed in relation to the selected articles set in Ghana. The paper relies on a content analysis of Trials of Brother Jero and similar themes presented in the selected articles, and makes a few recommendations on how these religious issues could be partially, if not wholly, resolved in Ghana.

Sam, C. A.'s paper, "Decolonizing the Postcolony: Of Men, Spatial Politics and the New Nation in WA Thiongo's Wizard of the Crow", examines how Ngugi Wa Thiongo's Wizard of the Crow blatantly explores Africa's complicity in a seemingly cyclic colonization in the $21^{\text {st }}$ century and its attendant consequences for the total liberation of Postcolonial Africa. The study examines the correlation between masculine representations, spatial reorganization and futurity as alternative ways in thinking about Africa's future through Bakhtin's theory of the carnival and other such concepts as polyphony and the grotesque. The result of the analysis is that the correlation between forms of communities and forms of masculinities is an indication of a vision of hope for Postcolonial Africa. 
Kambou, M. K. \& Traore, S. A. in "Manipulation and the popular uprising in Burkina Faso in 2014", analyse the different discourses in the build-up to the popular uprising in Burkina Faso on the $30^{\text {th }}$ and $31^{\text {st }}$ October 2014. It attempts to clarify how political and civil society leaders use language and other non-linguistic elements to influence the ordinary citizens' minds and, indirectly, their actions. The analysis is premised on Van Dijk's (2006) Sociocognitive approach. The paper analyses the cognitive, the social and the discursive dimensions of manipulation in six political speeches (two speeches from Civil Society, two from the ruling party and two from the political opposition). The results suggest that the three groups manipulated their audiences, and finally, the ruling party lost following the resignation of the then Head of State, making way for a Transition government to take over the reins of governance.

De-Souza, A. Y. M.'s paper “'Test-taking Strategies of University of Cape Coast Students of French as a Foreign Language: a Case Study.” seeks to provide a description of test-taking strategies that may inform teaching and learning of French for better output in tests against the background that Ghanaian students of French as a foreign language deploy strategies that are not adequate enough in answering test items in French. The study examines data gathered right after a French test by level 200 students, using recollective verbalization protocols.

Kambou, M. K. \& Soma, L. examine in their paper titled, "Local Culture and EFL Vocabulary Learning”, the influence of learners' culture on foreign language vocabulary. The paper seeks to demonstrate that there is a link between culture and lexico-semantic errors committed by learners of English as a foreign language among Dioula speaking students in Burkina Faso. A language test composed of two written activities was used as the data collection instrument. The results revealed that the Dioula speakers' English is influenced by their culture. These results have some pedagogical implications. They, therefore, suggest that we adapt the teaching of EFL vocabulary to learners' culture.

Kabore, A. \& Nazortin, C. in "Critical Analysis of the Place and Importance of Literature in the Teaching / Learning of English and in School Leaving Certificate Examination in Burkina Faso from 1985 to 2018", analyse the types of texts given at the "Baccalaureate A" written examination in the last thirty years. In this study, quantitative and qualitative 
data are collected. Baccalaureate written English papers are the main focus of our collection. Teachers and supervisors are interviewed. The study is grounded on "Reader-Response Theory" which stresses the interactions between the reader and the text. The results of the study show that the great majority of texts proposed for "Baccalaureate A" examination, in the last thirty years, are non-literary texts.

Malgoubri, I., Sawadogo, M. \& Kambou, M. K.’s paper titled, “Digital Audio-visuals Aids and Listening in English as a Foreign Language Classrooms", is an experimental study which investigates the potential of digital audio-visuals to improve the listening skills of EFL learners in secondary schools in Burkina Faso. On the assumption that learners born around the year 2000 are digital natives, the researchers try integrating smartphone-friendly audio-visuals in their EFL classrooms in a four-week experiment involving one Experimental Group and one Control Group. The experiment aims at gauging the effectiveness of those aids operated via students' smartphones in improving learners' listening and speaking skills. Independent T-tests were used to compare the groups and Sample Paired TTests to make comparisons within groups. The study suggests that, if appropriately used, smartphones are excellent devices for language teachers and learners in this digitizing world.

Osei, R. N. \& Inusah, H.'s paper, “A Critique of the Images of Heaven in the Scriptures of the Abrahamic Religions: An Existentialist Perspective." Critically examines the scriptural images of heaven as captured in the Abrahamic religions - Judaism, Christianity and Islam - from the existentialist perspective. The paper argues that the idea of life beyond this earthly existence for all human beings in a specially prepared location by God for eternal happiness for those who obey His commands on earth called Heaven, as propounded by the Abrahamic Religions, throws up a lot of problems, especially from the existentialist perspective. The study concludes that the scriptures' constructs of heaven appear self-contradictory and fail to strike a chord with the contemporary image of the ideal society when perused from the existentialist perspective and should, therefore, be discarded.

Negedu, A. K.'s paper "Lexical Gaps and Ideological Shift in the Translation of Chinua Achebe's Things Fall Apart as "Le Monde S'effondre" in French." examines the ideological divergence between the title of the original text and the title of the translation, following an observation 
that in translating Chinua Achebe's Things Fall Apart, Michel Ligny translates directly Igbo terminologies, realities and beliefs into the French language. The paper concludes that the ideology that the translated title projects to French-readers is totally different from the ideology that the original title projects to English-readers.

Talburt, T., in "Political Transformation and Development in Africa: Lessons from Achebe's Things Fall Apart", formulates critical perspectives on the significance of Achebe's novel for the socio-political and economic transformation and development of the African continent. The paper challenges one of the central assumptions in this story that Africa falls apart as soon as it comes in contact with Europe. It questions aspects of political conservatism exhibited in Okonkwo who is suspicious of fundamental changes to his society. The discussion is based on the jollof rice principle of political hybridisation of development which proposes the amalgamation of Westernised and non-Western ideas and systems, in order to achieve economic development, rather than totally rejecting Westernisation in its entirety. The study uses examples of Western-style democracy and State intervention in Africa to demonstrate the significance of embracing some aspects of Westernisation through political hybridisation. 




\title{
Digital Audio-visuals Aids and Listening in English as a Foreign Language Classrooms
}

\author{
Inoussa Malgoubri, Mahamadou Sawadogo \& Moses Kwadwo Kambou \\ Université Joseph Ki-Zerbo, Burkina Faso.
}

\begin{abstract}
Many scholars and language practitioners have stressed the importance of listening and speaking in language learning and teaching particularly in formal contexts. However, learners of English as a Foreign Language (EFL) in Burkina Faso appear to perform very poorly in those basic language skills. This experimental study investigates the potential of digital audio-visuals to improve the listening skills of EFL learners in secondary schools in Burkina Faso. Assuming that learners born around the year 2000 are digital natives, we have tried to integrate smartphone-friendly audio-visuals in their EFL classrooms in a four-week experiment involving one Experimental Group and one Control Group. The experiment aimed at gauging the effectiveness of those aids operated via students' smartphones in improving learners' listening and speaking skills. Independent T-tests were used to compare the groups and Sample Paired T-Tests to make comparisons within groups. Furthermore, Cohen's $d$, an effect size formula, was used to measure the effect size. The findings show that the listening skills of the students exposed to the digital audio-visual aids improved on average from 10.2 to 18.5. It was noticed incidentally that their speaking skills improved as well. The study suggests that, if appropriately used, smartphones are excellent devices for language teachers and learners in this digitizing world.
\end{abstract}

Keywords: audio-visual aids; control group; English as a Foreign Language (EFL); experimental group; Information and Communication Technology (ICT); listening comprehension. 


\section{Introduction}

As the international language mostly used around the world in business, science and technology, and international relations, English has logically made its way into the educational system of Burkina Faso, a francophone country. English is taught in secondary schools as a foreign language, and allotted 5 hours per week in 6è and 5è (Junior High School 1 and 2) and 3 hours a week fin 4è, 3è, 2nd, 1ère and Tle classes (Junior High School 3, 4 and Senior High School 1, 2, and 3) regardless of whether English is a compulsory subject or not.

The inclusion of Information and Communication Technology (ICT) in education is no longer a luxurious thing but a necessity as learners from one country may find themselves in another country during the schooling/learning period and use this tool to follow the courses back home. Therefore, teachers have the responsibility to continue updating their teaching methods and teaching aids, in the same line, Perraton et al. (2001) say that teaching is becoming more and more demanding as knowledge is expanding rapidly and much of it is available to students as well as teachers at the same time. As far as learning concepts evolve, teachers should facilitate learning and make it meaningful to individual learners rather than to just provide knowledge and skills. As new concepts of learning evolve, teachers are expected to facilitate learning and make it meaningful to individual learners rather than to provide knowledge and skills.

"Modern developments in innovative technologies have provided new possibilities to the teaching professions, but at the same time have placed more demand on teachers to learn how to use these new technologies in their teaching" Robinson \& Latchem (2003) quoted in Jung (2005:01). Unfortunately, most teachers are left to fend for themselves in the midst of many technologies to find the most appropriate ways for their specific teaching environment. Combining new technologies with effective pedagogy has become a daunting task for both teachers and teacher-training colleges.

The education authorities of Burkina Faso set the following language policy, "Every learner at the end of a given cycle should be able to hold a regular communication with a native peer of the same level" (Ministry of education, 1983) ${ }^{1}$. This goal is unrealistic owing to the materials available and the teaching environment which allows very little or no exposure of the students to English as spoken by their native peers of the same level.

There is a huge gap between the goal expected by the Ministry of Education and the observation of education supervisors. The English Inspectorate (2011:3) observed that "during class visits and inspections, most English teachers in Burkina Faso teach grammar and reading basically, and 
those teachers who tried [sic] productive activities did something else." This observation reveals that EFL teachers and learners are not doing enough to achieve the expected outcome of teaching/learning EFL. Dramé (2008) conducted a survey where $100 \%$ of respondents said their teachers used printed texts to conduct listening comprehension activities. When we compare the observations made by the English inspectorate of Burkina Faso and current practices, it can be inferred that this situation does not help attain the objectives of teaching/learning EFL. In order to help reach the EFL teaching/learning objectives, we have a wide range of resources such as digital audio-visuals which can help through the use of ICT resources for English learning. ICTs "include technologies such as desktop and laptop computers, software, peripherals, and connections to the internet that are intended to fulfil information processing and communications functions" (Statistics Canada, quoted by Amjad et al., 2016: 2). Singh, Cheok, and Ng (2005: 237) define audio-visual aids as "any device which by sight and sound increases the individuals' experience beyond that acquired through reading". They can be downloaded/uploaded and shared with other devices through file sharing systems. ICT provides online digital audio-visual aids which allow great choices and controls which can be adapted to the learners' needs. These audiovisual aids (AVs) are not only useful resources for the EFL teacher but a must since learners born around and after the year 2000 are "digital natives" as coined by Prensky (2001). This study tries to find out if digital AVs can help EFL teachers better than common teaching aids such as printed texts and tape recorders. Secondly, it aims at assessing the effectiveness of digital audio-visual aids in the EFL classes to enhance EFL learners' listening skills.

\section{Listening comprehension in the literature}

Definitions of listening comprehension have been provided by many scholars around the world, basically describing it as the ability to comprehend native speech at normal speed. Morley (1972) quoted in Cheug (2010:04) specifies that it "involves auditory discrimination, aural grammar, selecting necessary information, remembering it, and connecting it to the process between sound and form of meaning". It appears that listening is not a passive skill as assumed in the heyday of the Audio-Lingual Method. Hamouda (2013:117) also defines listening comprehension as "an interactive process in which listeners are involved in constructing meaning". In addition to these definitions, Nadig (2013) as quoted by Pourhosein (2016:124) says that "listening comprehension is the various processes of understanding and making sense of spoken language." Listening comprehension consists of the 
ability to make sense of what is heard and perform an inferred action i.e. doing something that the speaker asked to.

\section{Listening processes}

The listener resorts to two processes to make sense of the incoming information known as bottom-up and top-down listening. When the learner decodes the incoming sounds starting from the smallest unit to the complete text, it is called top-down processing. Top-down processing is explained as employing background knowledge in comprehending the meaning of a message. It requires background knowledge and a good command of the phonetics, grammar, and syntax of the language being listened to. Bottom-up processing is when the listener starts from the phonemes to complete texts. These processes are not mutually exclusive, and the listener may resort to checking or asking for clarification in an interactive mode. So, good listeners resort to different strategies and processes to make sense of the incoming data. Digital audio-visuals provide learners with visual effects such as gestures, facial expressions, and proxemics, kinetic clues which assist the learner in the processing of the message they hear.

\section{Listening strategies}

Comprehending listening passages requires processes and strategies so as to clearly grasp what is said. Learners resort to cognitive, meta-cognitive and socio-affective strategies as identified by Rost and Ross (1991). Cognitive strategies are related to understanding and gathering input in short-term memory or long-term memory for later use. Comprehension begins with the received information. Then, the listener examines the piece of information following levels of formation and a process of decoding the meaning. In the decoding process, the listener may use meta-cognitive strategies. These are strategies deployed when the listener uses extra knowledge to make sense of the incoming data. They can easily be used by proficient learners of the language. Salataci (2002) indicates that the use of metacognitive strategy in the listening process increases learners' self-confidence, motivation, and ability to complete the activities. Vandergrift (2003) and Abdalhamid (2012) define socio-affective strategies as techniques that listeners use to cooperate with others, to check their comprehension, and to reduce their apprehension. Apart from these strategies, there are listening strategies that Nunan (1999) identified and referred to as purposive listening strategies. For instance, we have listening for main idea, for specific information, listening for tone, listening for inference, etc. 


\section{ICT and listening}

Previous studies showed that students know about or use ICT and teachers must take advantage of it to improve students' performance by using them because today's students are "digital natives" and their teachers "digital immigrants" (Prensky, 2001:1-2).

The use of digital AVs in the classroom has been a subject of study for many linguists and educational researchers. Stempleski \& Arcario (1991) reveal five major tendencies in the use of video: (a) integration of video with other content; (b) teacher-made support materials; (c) teacher-house video production; (d) emphasis on aural/oral skills; (e) on cultural content. (Lonergan, (1992) and Forrest (1993).

In Burkina Faso, the integration of the digital audio-visuals in teachertraining dates back to the 90s with the National Institute of Education Science (INSE), Béogo (2016). It consisted in recording a teacher in a classroom. This recorded video was then used in the teacher-training college. It was used for in-service training to allow participants to reflect on their peers' weaknesses and strengths, to build on those strengths and attend to their weaknesses.

Furthermore, Nikièma (2016) conducted a survey to have insights on the impact of the digital audio-visuals on the new pedagogical approach called "Approche Intégratrice" (API), that is Integrative Approach which allows learners to gather and process without barriers between, study subjects. He found that teachers appreciate digital AVs, but this research was about digital audiovisuals in primary school teacher-training and aimed at helping teachers reflect on their peers' weaknesses and strengths to improve their daily classroom activities.

Some studies on listening comprehension were conducted in Burkina but they hardly ever involved an experimental approach to the use of digital AVs as undertaken in this one.

\section{Design and Methods}

\section{Study population}

The target population is art-oriented students of 2ndeA (Senior High School 1). Purposive sampling was used for this study. Students of 2 ndeA have been studying English for at least four years and can do some complex listening activities. Secondly, English is a compulsory subject for them. Furthermore, English is the third subject in terms of weighting in this level with a factor ${ }^{2}$ of 4 , after philosophy and French which have a factor of 5 each. 
The age range is $18-20$ according to the normal schooling system and they may be allowed to use cell phones.

\section{Sampling}

The students selected for this study were 18 years old or above and had smartphones or access to other devices which support digital AVs: students can use their parents', friends' or siblings' laptops, desktop or smartphones. According to the statistics of the 2016/2017 school year, the Région du Centre (Center Region) counts 65,194 second cycle students regardless of their options. This study involved students of Senior High School 1 (2ndeA) divided into two groups: a control group (CG) of 10 students and an experimental group (EG) of 11 students.

\section{The experiment}

The experiment consisted of a pre-test and a post-test used to gauge the impact of the intervention (experiment). It is divided into three phases: the situation before the experiment, the experiment itself and the situation after the experiment.

\section{The design of the experiment}

The research design is quasi-experimental. It is a term used to describe a research design that uses the same design and process as the experimental approach but which, for practical reasons, cannot meet one or the other essential element conditions (Denscombe, 2014).

In this study, students were randomly divided into two groups - one control group and one experimental group. Both groups had the same teacher and took the same activities in a Pre-test-Post-test designed for their level. The pre-test served as a baseline for comparison purposes. The post-test was used to see how the students performed after the experiment.

\section{Pre-test-Post-test}

A pre-test and a post-test were used i.e. tests before and after the treatment in order to gauge the impact of the experiment or treatment. Both tests consist of gap filling, multiple choice, and true/false questions to measure the learners' listening skills. Objective test items were used as they have intragrader and inter-grader reliabilities. They measure the extent to which the use of digital AVs improves the students' listening abilities. They test the students' ability to comprehend spoken discourse related to various language functions. 
There were 25 items subdivided into three different competence levels and each level covered two situations and language functions - asking for permission, asking for personal information, offering and ordering, advising, asking for people's activities, describing free time activities.

\section{Evaluation of the Pre-test-Post-test}

At the Post-tests, an improvement from the Pre-tests of the experimental group was expected. The experimental group was expected to outscore the control group by having medium to large effect according to Cohen's $d$. It is only when the effect size is medium and above, that it could be said that the use of digital audio-visuals was effective in improving EFL learners' listening skills.

\section{Findings and Discussion}

In this section, we have the findings of the Pre-test and the Post-test, the discussion of the results, and their implications. Two types of t-test were used. Independent T-tests are used when we compare two groups, that is between group comparison i.e comparing CG and EG. Paired Sample T-tests are employed when we compare the pre-test and post-test of the same group, that is within group comparison i.e. comparing the performances before and after the experiment of the same group.

\section{Findings of the Pre-test}

In order to control variables prior to the experiment, the pre-test was administered to serve as a baseline to find out whether there were statistically significant differences between the control and the experimental groups in terms of listening comprehension.

\section{Comparison between the performance of the students in Control Group and Experimental Group}

Table 1: Group statistics CG vs EG

\begin{tabular}{|l|c|c|c|c|c|}
\hline \multicolumn{7}{|c|}{ Group Statistics } \\
\hline Group & & $\mathrm{n}$ & Mean & $\begin{array}{c}\text { Std. } \\
\text { Deviation }\end{array}$ & $\begin{array}{c}\text { Std. Error } \\
\text { Mean }\end{array}$ \\
\hline Pre-test & CG & 10 & 11.400 & 1.1738 & .3712 \\
\cline { 2 - 6 } & EG & 11 & 10.182 & 1.8340 & .5530 \\
\hline
\end{tabular}

Source: Field data, 2018 
Table 2: Independent Samples Test CG vs EG

\begin{tabular}{|c|c|c|c|c|c|c|c|c|c|c|}
\hline & \multicolumn{2}{|c|}{$\begin{array}{c}\text { Levene's } \\
\text { Test for } \\
\text { Equality of } \\
\text { Variances }\end{array}$} & \multicolumn{7}{|c|}{ t-test for Equality of Means } \\
\hline & & \multirow[t]{2}{*}{$\mathrm{F}$} & \multirow[t]{2}{*}{ Sig. } & \multirow[t]{2}{*}{$\mathrm{T}$} & \multirow[t]{2}{*}{$\mathrm{df}$} & \multirow[t]{2}{*}{$\begin{array}{l}\text { Sig. (2 } \\
\text { tailed) }\end{array}$} & \multirow[t]{2}{*}{\begin{tabular}{|c|} 
Mean \\
Dif.
\end{tabular}} & \multirow[t]{2}{*}{$\begin{array}{c}\text { Std. } \\
\text { E } \\
\text { Dif. }\end{array}$} & \multicolumn{2}{|c|}{$\begin{array}{c}95 \% \\
\text { Confidence } \\
\text { Interval of the } \\
\text { Difference }\end{array}$} \\
\hline & & & & & & & & & Lower & Upper \\
\hline \multirow[b]{2}{*}{$\begin{array}{l}\text { Pre- } \\
\text { test }\end{array}$} & \begin{tabular}{|l} 
Equal \\
variances \\
assumed
\end{tabular} & 5.330 & .032 & 1.791 & 19 & .089 & 1.2182 & 6801 & -.2053 & 2.6417 \\
\hline & \begin{tabular}{|l} 
Equal \\
variances \\
not \\
assumed \\
\end{tabular} & & & 1.829 & 17.169 & .085 & 1.2182 & .6660 & -.1859 & 2.6223 \\
\hline
\end{tabular}

\section{Source: Field data, 2018}

Table 1 shows Independent T-Test result of Control Group (CG) and the Experimental Group (EG). We can see that the means of the Control Group (CG) and the Experimental (EG) are close. Table 2 shows the Levene's Test of Equality of variances where the groups are homogenous as Equal variances are assumed. The p-value, that is (sig. tailed), is .089 is well above 0.05 . We can infer that there is no statistically significant difference between both groups at the pre-test.

\section{Findings of the Post-test}

After the experiment, the same test was administered. When the pvalue (sig. tailed) is less than 0.05 , it can be inferred that the difference between the pre-test and the post-test is statistically significant. When it is above 0.05 , it means that the treatment had no significant impact on the students from the pre-test to the post-test and therefore the digital audio-visual aids do not help to improve EFL learners' listening skills. In case the mean scores of the pre-test and the post-test are statically significant, the effect size (d) was calculated according to the formula provided by Cohen: $d=\frac{\text { Mean }}{\text { SD }}$ to calculate the $d$ value. 
The referential framework to identify the effect size is as follows:

Table 3: The referential framework for identifying the effect size

\begin{tabular}{|l|l|}
\hline The d value (effect size) & Interpretation \\
\hline 0.2 till less than 0.5 & Small \\
\hline 0.5 till less than 0.8 & Medium \\
\hline 0.8 or more & Large \\
\hline
\end{tabular}

Source: Field data, 2018

Comparison between Control Group (CG) and Experimental Group after the treatment

Table 4: Group statistics CG vs EG

\begin{tabular}{|l|l|l|l|l|l|}
\hline \multicolumn{2}{|l|}{ Group } & $\mathrm{n}$ & Mean & Std. Deviation & Std. Error Mean \\
\hline \multirow{3}{*}{ Pre-test } & CG & 10 & 11.400 & 1.1738 & .3712 \\
\cline { 2 - 6 } & EG & 11 & 10.182 & 1.8340 & .5530 \\
\hline \multirow{2}{*}{$\begin{array}{l}\text { Post- } \\
\text { test }\end{array}$} & CG & 10 & 12.700 & 1.7670 & .5588 \\
\cline { 2 - 6 } & EG & 11 & 18.455 & 4.2039 & 1.2675 \\
\hline
\end{tabular}

Source: Field data, 2018 
Table 5: Independent Samples Test CG vs EG

\begin{tabular}{|c|c|c|c|c|c|c|c|c|c|c|}
\hline & \multicolumn{2}{|c|}{$\begin{array}{l}\text { Levene's } \\
\text { Test for } \\
\text { Equality of } \\
\text { Variances }\end{array}$} & \multicolumn{7}{|c|}{ t-test for Equality of Means } \\
\hline & & \multirow[t]{2}{*}{$\mathrm{F}$} & \multirow[t]{2}{*}{ Sig. } & \multirow[t]{2}{*}{$\mathrm{T}$} & \multirow[t]{2}{*}{ df } & \multirow[t]{2}{*}{$\begin{array}{l}\text { Sig. (2- } \\
\text { tailed) }\end{array}$} & \multirow[t]{2}{*}{$\begin{array}{c}\text { Mea } \\
\mathrm{n} \\
\text { Diff. }\end{array}$} & \multirow[t]{2}{*}{$\begin{array}{l}\text { Std. } \\
\text { Error } \\
\text { Diff. }\end{array}$} & \multicolumn{2}{|c|}{$\begin{array}{c}95 \% \\
\text { Confidence } \\
\text { Interval of } \\
\text { the } \\
\text { Difference }\end{array}$} \\
\hline & & & & & & & & & Lower & Upper \\
\hline \multirow[t]{2}{*}{$\begin{array}{l}\text { Pre- } \\
\text { test }\end{array}$} & $\begin{array}{l}\text { Equal } \\
\text { variances } \\
\text { assumed }\end{array}$ & 5.330 & .032 & 1.791 & 19 & .089 & 1.2182 & .6801 & -.2053 & 2.6417 \\
\hline & $\begin{array}{l}\text { Equal } \\
\text { variances } \\
\text { not } \\
\text { assumed }\end{array}$ & & & 1.829 & 17.169 & .085 & 1.2182 & .6660 & -.1859 & 2.6223 \\
\hline \multirow[t]{2}{*}{$\begin{array}{l}\text { Post- } \\
\text { test }\end{array}$} & $\begin{array}{l}\text { Equal } \\
\text { variances } \\
\text { assumed }\end{array}$ & 6.419 & .020 & -4.011 & 19 & .001 & -5.7545 & 1.4346 & -8.7572 & -2.7519 \\
\hline & $\begin{array}{l}\text { Equal } \\
\text { variances } \\
\text { not } \\
\text { assumed }\end{array}$ & & & -4.154 & 13.690 & .001 & -5.7545 & 1.3852 & -8.7319 & -2.7772 \\
\hline
\end{tabular}

\section{Source: Field data, 2018}

Tables 4 and 5 show Independent T-Test results of Control Group and the Experimental Group (EG). The means of the Control Group (11.4) and the Experimental (10.2) are close at the pre-test whereas the EG scored better than CG at the post-test (18.5 vs. 12.4). The Levene's Test of Equality of variances shows that the groups are homogenous as Equal variances are assumed. The p-value was .085 at the pre-test and 0.001 at the post-test. Since there was no significant difference between both groups at the pre-test, the difference at the post-test is considered to be due to the treatment. It can, therefore, be concluded that EG outscored CG at the post-test and the treatment was effective. In the next tables, Paired Samples statistics will be used to show how well each group did compared with its performances at the pre-test and post-test. 


\section{Comparison between the pre-test and post-test of each group Performance of Control Group (CG)}

Table 6: Paired Samples Statistics CG

\begin{tabular}{|l|l|r|r|r|r|}
\hline \multicolumn{2}{|c|}{} & \multicolumn{1}{c|}{ Mean } & $\mathrm{n}$ & \multicolumn{1}{c|}{$\begin{array}{c}\text { Std. } \\
\text { Deviation }\end{array}$} & $\begin{array}{c}\text { Std. Error } \\
\text { Mean }\end{array}$ \\
\hline $\begin{array}{l}\text { Pair } \\
1\end{array}$ & Pre-test & 11.400 & 10 & 1.1738 & .3712 \\
\cline { 2 - 6 } & Post-test & 12.700 & 10 & 1.7670 & .5588 \\
\hline
\end{tabular}

Source: Field data, 2018

Table 7 : Paired Samples Correlations CG

\begin{tabular}{|l|l|r|r|r|}
\hline \multicolumn{2}{|c|}{} & $\mathrm{n}$ & Correlation & Sig. \\
\hline Pair 1 & $\begin{array}{l}\text { Pre-test \& Post- } \\
\text { test }\end{array}$ & 10 & .118 & .746 \\
\hline
\end{tabular}

Source: Field data, 2018

Table 8: Paired Samples Test CG

\begin{tabular}{|c|c|c|c|c|c|c|c|c|}
\hline & \multicolumn{5}{|c|}{ Paired Differences } & \multirow[t]{3}{*}{$\mathrm{t}$} & \multirow[t]{3}{*}{ df } & \multirow{3}{*}{$\begin{array}{l}\text { Sig. } \\
(2- \\
\text { tailed) }\end{array}$} \\
\hline & \multirow[t]{2}{*}{ Mean } & \multirow[t]{2}{*}{$\begin{array}{c}\text { Std. } \\
\text { Deviation }\end{array}$} & \multirow[t]{2}{*}{$\begin{array}{l}\text { Std. } \\
\text { Error } \\
\text { Mean }\end{array}$} & \multicolumn{2}{|c|}{$\begin{array}{c}95 \% \\
\text { Confidence } \\
\text { Interval of the } \\
\text { Difference }\end{array}$} & & & \\
\hline & & & & Lower & Upper & & & \\
\hline Pair $1 \mid \begin{array}{l}\text { Pre-test } \\
- \text { Post- } \\
\text { test }\end{array}$ & -1.3000 & 2.0028 & .6333 & -2.7327 & .1327 & -2.053 & 9 & .070 \\
\hline
\end{tabular}

Source: Field data, 2018

Tables 6,7 , and 8 show that students who were not exposed to the use of the audio-visual aids during the experiment did not improve after the experiment as there is no statically significant difference in scores on both tests. The pvalue is .070 and it is above the $0.05,(p>0.05)$.

\section{Performance of Experimental Group (EG)}

Table 9: Paired Samples Test EG

\begin{tabular}{|c|c|c|c|c|c|}
\hline \multicolumn{2}{|c|}{} & Mean & $n$ & Std. Deviation & $\begin{array}{c}\text { Std. Error } \\
\text { Mean }\end{array}$ \\
\hline \multirow{2}{*}{ Pair 1 } & Pre-test & 10.182 & 11 & 1.8340 & .5530 \\
\cline { 2 - 6 } & Post-test & 18.455 & 11 & 4.2039 & 1.2675 \\
\hline
\end{tabular}

Source: Field data, 2018 
Table 10: Paired Samples Correlations EG

\begin{tabular}{|l|l|l|l|l|}
\hline \multicolumn{2}{|l|}{} & $n$ & $\begin{array}{l}\text { correlati } \\
\text { on }\end{array}$ & Sig. \\
\hline Pair 1 & Pre-test \& Post-test & 11 & .559 & 0.74 \\
\hline
\end{tabular}

Source: Field data, 2018

Table 10: Paired Samples Test EG

\begin{tabular}{|c|c|c|c|c|c|c|c|c|c|}
\hline & \multicolumn{5}{|c|}{ Paired Differences } & \multirow[t]{3}{*}{$\overline{\mathrm{T}}$} & \multirow[t]{3}{*}{$\overline{d f}$} & \multirow{3}{*}{$\begin{array}{l}\text { Sig. } \\
(2- \\
\text { tailed })\end{array}$} \\
\hline & & \multirow[t]{2}{*}{ Mean } & \multirow[t]{2}{*}{$\begin{array}{c}\text { Std. } \\
\text { Deviation }\end{array}$} & \multirow[t]{2}{*}{$\begin{array}{l}\text { Std. } \\
\text { Error } \\
\text { Mean }\end{array}$} & \multicolumn{2}{|c|}{$\begin{array}{l}95 \% \text { Confidence } \\
\text { Interval of the } \\
\text { Difference }\end{array}$} & & & \\
\hline & & & & & Lower & Upper & & & \\
\hline ir 1 & $\begin{array}{l}\text { Pre-test } \\
- \text { Post- } \\
\text { test }\end{array}$ & -8.2727 & 3.5239 & 1.0625 & -10.6401 & -5.9053 & 7.786 & 10 & .000 \\
\hline
\end{tabular}

\section{Source: Field data, 2018}

Tables 9, 10, and 11 show that the Experimental Group (EG) students who were exposed to the use of the digital audio-visual aids during the experiment did something different at the post-test. This difference in score shows that EG students performed better than those of the Control Group who were not exposed to the digital AVs. The observed level of significance for the test is 0.00 ( $\mathrm{p}<0.05)$. This points to the fact that the performance of the Experimental Group (EG) which took part in the experiment is statistically more significant than that of the Control Group. Therefore, it can be concluded that they improved after the experiment thanks to the use of digital audio-visuals. For more reliability and to measure the extent to which the experiment was effective, the effect size on students' listening skills was computed according to the formula suggested by Cohen (2013). The calculated effect size for the Experimental Group is (2.34) $>0.8$. Therefore, it can be inferred that the use of digital AVs had a very large effect on the students' listening performance at the post-test. 
Figure 1 shows the improvement of each group after the experiment and the Mean scores of the CG and EG at Pre-test and Post-test.

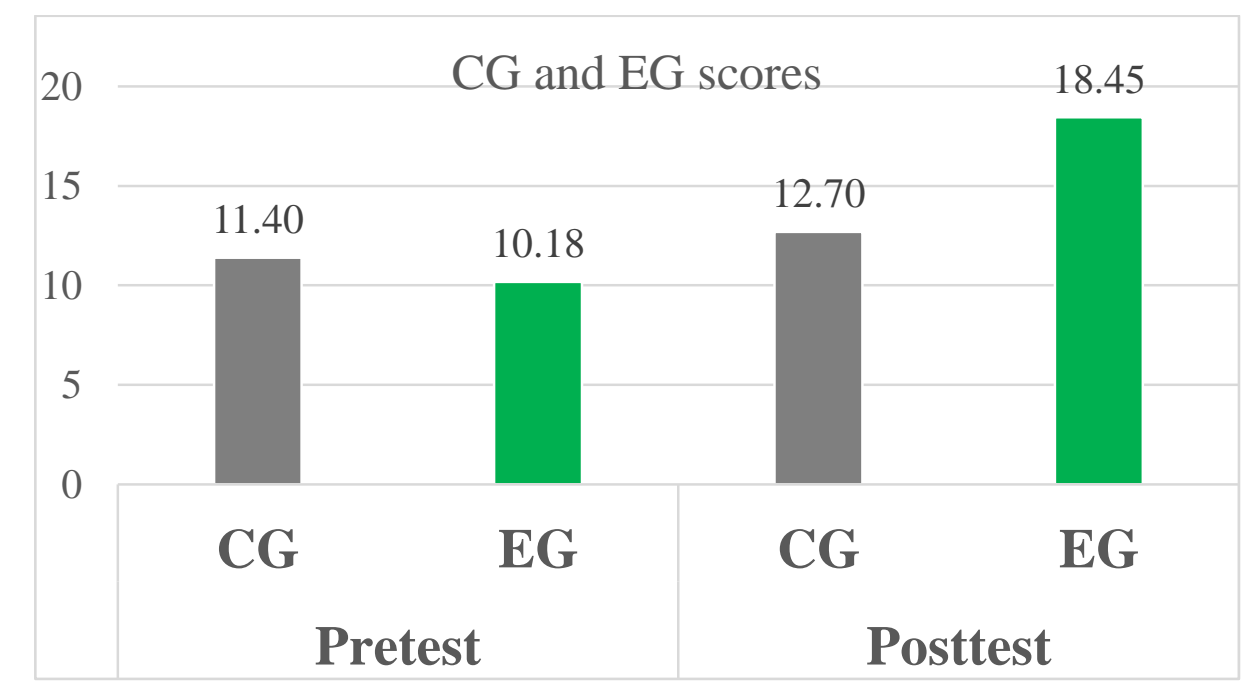

Source: Field data, 2018.

\section{Discussion}

The analysis of the results shows that the use of digital audio-visual aids in the EFL classroom is beneficial to the learners. At the Pre-test, all the students regardless of their groupings were similar. The equalities of variances were assumed in the two groups from each class and there were no significant differences between all the groups at each level (See Tables 1-2).

The experiment revealed that the listening skills of students have improved. For instance, the mean score of the Control Group of (CG) at the pre-test was 11.4 and their mean score at the post-test was 12.4. The sample paired test showed that both groups made some progress when we look at the mean scores of the groups. The paired samples statistics using SPSS v.21.0 showed that the progress made by the Control Group was not statistically significant. The difference from pre-test to post-test is statistically significant in the Experimental Group. EG moved from 10.82 to 18.45. The progress they made was large according to the effect size calculated using Cohen's $d$. The effect size calculation helped to measure the strength of each teaching aid/method.

The experiment revealed that the use of digital AVs is effective with the students as the results were significant in the experimental group. This study revealed that the use of the digital AVs is effective in enhancing EFL learners' listening skills. Students may have access to other learning 
opportunities but the smartphone friendly AVs constitute stimulus for permanent learning as reported by students themselves. Once home, students resort to people around them to make sense of what they watch. It leads students to use Socio-affective strategies. Digital AVs provide students with linguistic clues to better understand the spoken passage. Purdy (1997) once observed that listeners do not passively absorb the words, but actively attempt to grasp the facts and feelings in what they hear by attending to what the speaker says, to how the speaker says it, and to the context in which the message is delivered.

As the digital AVs greatly impacted students' listening, it was also observed that they significantly impacted on their speaking as well. This shows that using digital AVs is very important in listening and speaking as the feeling, setting and the context are clear in the audio-visual. Dike (1993:87) stated that "once the phenomenon is visualized, the picture and knowledge become very clear and permanent".

Doosuur \& Sandra (2013: 45) said that:

audio-visual materials when effectively used have these advantages: they lessen major weaknesses, provide verbalism, humanize and vitalize subject matter, provide an interesting approach to new topics, give initial correct impressions, save time in learning, supply concrete materials needed, and stimulate listeners' initiative.

Natoli (2011:102) once added that "audio-visual materials are rich opportunities for students to develop communication skills while actively engaged in solving meaningful problems". The statistical analysis gives evidence that the use digital AVs enhances EFL learners' listening skills and this also infers that digital AVs have positive effects in the listening process and lessen difficulties and impediments that the learners encounter.

Swank (quoted in Akinwole, 2015:54) said that digital audio-visuals "are effective in learning as $40 \%$ of our concepts are based upon visual experience, $25 \%$ upon auditory, $17 \%$ upon tactile, $15 \%$ upon miscellaneous organic sensation and 3\% upon taste-smell". This buttresses the opportunity of permanent learning that digital AVs offer. Moreover, Fawcett (1994) quoted in Akinwole (2015:54) pointing the contributing role of audio-visual materials in stimulating interest stated that "A friendly, accepting group climate is important in any learning situations, especially those materials that require students to reveal their ignorance and confront their fellow students". When there is a climate of acceptance for learning, then learning is stimulated. The statistical analysis gives evidence that the use of digital AVs enhances EFL 
learners' listening skills. The effectiveness in listening comprehension showed that digital AVs have positive effects in the listening process of the learners. This effectiveness also impacted students' speaking throughout the experiment.

\section{Conclusion}

This study showed that digital AVs are effective in alleviating factors affecting EFL learners' listening comprehension. While students' listening skills were improving, it was noticed that, listening was pivotal in the acquisition of other skills and learners used diverse strategies to process it. After all, speaking is the skill which combines with listening to open doors wherever good communication is a prerequisite such as job interviews and business doing. The integration of ICT and digital in the language classroom allows teachers to keep pace with the fast digitalizing world and adapt to learners' learning styles. The findings imply that the ongoing teaching aids improve students' listening skills but it is very limited when compared to the digital audio-visuals. With digital natives as coined by Prensky (2001), the EFL curricula and syllabi should include the digital AVs to help learners improve their listening skills and provide opportunities for permanent learning. This study purported to investigate the effectiveness of digital AVs in improving EFL students' listening comprehension. From the results obtained after the experiment we can conclude that Smartphones are ICT materials which are helpful in the teaching and learning of listening comprehension and digital AVs are good alternatives to printed texts, reading aloud and tape recorders in listening comprehension.

\section{Notes}

1. Our translation of an excerpt of Circular 1983-105/MENA/ICESD of Ministry of education and culture of Burkina Faso on Foreign Language Teaching

2. Weight of grades in a given study subject. It ranges from 2 to 5 in Senior High School Year 1(2ndeA).

\section{References}

Abdalhamid, F. (2012). Listening comprehension strategies of Arabic-speaking ESL learners. (Master's Thesis). Colorado State University, USA.

Amjad, A., Ahmad, R. Jafar , I. (2016). ICT applications and user satisfaction in Aligarh Muslim University, Aligarh: a survey. Library Philosophy and 
Practice. Retrieved from https://go.galegroup.com/ps/i.do?id=GALE $\% 7 C A 471851640 \&$ sid $=$ googleScholar\&v $=2.1 \& \mathrm{it}=\mathrm{r} \&$ linkaccess $=\mathrm{abs} \& \mathrm{i}$ $\mathrm{ssn}=15220222 \& \mathrm{p}=\mathrm{AONE} \& \mathrm{sw}=\mathrm{w}$ on June 15, 2018.

Akinwole, O. I. (2015). The Effects of Audio-Visual Materials in the Teaching and Learning of the Speaking Skill in Junior Secondary Schools. International Journal of Social Science and Humanities Research, Vol. 3(Issue 3,), 50-58.

Béogo, J. (2016). Continuing Professional Training of Teachers in Burkina Faso: The Movie as a Fundamental Alternative System. Revue de Philosopbie, Littérature et Sciences Humaines, 003(007), 564-577.

Cohen, J. (2013). Statistical power analysis for the behavioral sciences. Routledge.

Denscombe, M. (2014). The good research guide: for small-scale social research projects: McGraw-Hill Education (UK).

Dike, V. W. (1993). Library resources in education: Abic Publishers.

Doosuur, A.\& Sandra M. I., (2013). The Use of Audio-Visual Materials in the Teaching and Learning Processes in Colleges of Education in Benue State-Nigeria. Journal of Research \& Method in Education. Vol 1(6), 44-55.

Dramé, S. (2008). Teaching Listening Comprehension. (Dissertation submitted for Advanced certificate for teacher supersvision), University of Koudougou, Koudougou.

Forrest, T. (1993). Technology and the language classroom. Available technology. TESOL quarterly, 27(2), 316-318.

Hamouda, A. (2013). An Investigation of Listening Comprehension Problems Encountered by Saudi Students in the EL Listening Classroom. International Journal of Academic Research in Progressive Education and Development, 2(2), 113155.

Lonergan, J. (1992). Using a video camera to evaluate learners' classroom performance. Video in second language teaching: Using, selecting, and producing video for the classroom, 93-105.

Natoli, C. (2011). The Importance of Audio-Visual Materials in Teaching and Learning. Retrieved from https://www.helium.com/channels/224-earlychildhood-edu on February, 20, 2016. 
Nikièma, N. J. (2016). Apport des supports audio-visuels dans la formation continue des enseignants de l'éducation de base primaire au Burkina Faso : cas de la vidéo intitulée "calcul : décomposition soustractive du nombre 15 au CP1 》 utilisée en vue de l'expérimentation de l'Approche Pédagogique Intégratrice(API). (TeacherTraining), University of Koudougou, Koudougou, Burkina Faso.

Nunan, D. (1999). Second Language Teaching \& Learning. Heinle \& Heinle Publishers, 7625 Empire Dr., Florence, KY 41042-2978.

Retrieved from https:// eric.ed.gov/?id=ED441344 on June 30, 2017.

Perraton, H., Robinson, B., \& Creed, C. (2001). Teacher Education through Distance Learning: Technology, Curriculum. Evaluation, Cost. Paris. UNESCO.

Pourhossein Gilakjani, A. (2016). English pronunciation instruction: A literature review. International Journal of Research in English Education, 1(1), 1-6.

Pourhosein Gilakjani, A., \& Sabouri, N. B. (2016). How can students improve their reading comprehension skill. Journal of Studies in Education, 6(2), 229-240.

Prensky, M. (2001). Digital natives, digital immigrants part 1. On the horizon, 9(5), 1-6.

Rost, M., \& Ross, S. (1991). Learner use of strategies in interaction: Typology and teachability. Language learning, 41(2), 235-268.

Salataci, R. (2002). Possible effects of strategy instruction on L1 and L2 reading. Reading in a foreign language, 14(1), 1.

Singh, S., Cheok, A., \& Ng, G. (2005). Mobile platform. In: Google Patents.

Stempleski, S., \& Arcario, P. (1991). Video and ESL in the US: Pilot survey results. TESOL Video News, 10.

The English Inspectorate of Burkina Faso (2011). Gè to 3è Class Syllabuses. Ministry of Education, Burkina Faso.

Vandergrift, L. (2003). Orchestrating strategy use: Toward a model of the skilled second language listener. Language learning, 53(3), 463-496. 
